\section{The ambiguity of 'semi-scholarly'}

I will gladly comment on the 'Comment' section of ET16 'A semi-scholarly medley?'. I think I was right to include $E T$ in a state-of-the-art account of English as a World Language in English World-Wide 9:1. Many of the articles in ET are on related topics, and the foundation of the journal and its apparent appeal world-wide appear to document an increasing interest in varieties of English and their historical and social determinants, on more and less scholarly levels, which I feel confirms my own work in the field.

Much of what is published in $E T$ is not, and is not intended to be, scholarly. So the journal is indeed a medley in the descriptive sense you quote from Collins. The 'semi-scholarly' is intended to be ambiguous: most of the contributions of more scholarly interest are too short, and not sufficiently supplied with data and references to existing research to satisfy more academically oriented readers. But this is not the readership you aim at - so my descriptive term is not a criticism. Also, differences in attitudes and approach are a necessary precondition for scholarly discussion.

I continue to have difficulties ('amazingly') in fitting $E T$ into my view (preconception?) of Cambridge University Press as an 'eminently respectable academic publisher', 'The Oldest Press in the World'. Perhaps my view is wrong, or the concept of scholarly writing is in the process of changing.

I have nothing against the element of 'entertainment and fun' mentioned in Ms. Wajnryb's letter - indeed quite the contrary is true, as my translations and editions of Max and Moritz (ET12) will show. We are, of course, all aware of the fact that what is funny (or serious) to one (type of) reader will not necessarily be so to another.

Professor Manfred Görlach, Englisches Seminar, Universität zu Köln, West Germany.

\section{In favour of girls}

Valerie Yule's comments (ET 16, Oct 88) on OUP's efforts to wipe out ladies and replace them with all-purpose women reminds me of another endangered species girls. Some months ago I rashly asked a colleague after a meeting, 'Who was that pretty girl sitting next to you?' Rather than tell me, this mfb (yes, I'm afraid it was that rampaging species, the male feminist boar) attacked: 'She's not a girl, she is of childbearing age, she's a woman.' I mildly remonstrated that, sadly, some eleven-year-olds had been known to give birth, and were we now to talk of schoolwoman mothers? Next time I saw the subject of my query - a postgraduate research student of I'd guess about twenty-five - I took the opportunity of asking whether she herself would like to be referred to by others as a female, a girl, a lady or a woman. Her reply was instant: 'Oh, a girl as long as possible.' Long live girls!

Sylvia Chalker,

Highgate, London, England.

\section{Ghoti and School}

In the July 88 issue you asked for opinions about placing the letters at the back of the magazine. I, for one, enjoy having them up front. They are the first things I read, since they have comments and reactions from readers around the globe. But wherever you put them, I'll find them.

The cartoon, page 61 , lower right, reminds me of a very old story about an immigrant who was taking English in his immigrant/citizenship class. The word fish was called out, he spelled it ghoti. Called upon for an explanation, he rationalized, ' $\mathrm{GH}$ as in rough, $\mathrm{O}$ as in women, $\mathrm{TI}$ as in nation'.

On my first visit to the UK in 1979, I was spending the first part of a rainy February afternoon in a cozy pub behind Liberty's. We had a good group, and I was catching what-for as one of the American colonists whose ancestors had taken a significant part in our Revolution (American Rebellion to you). To close out the subject, a very pleasant Rhodesian said he could understand how a language could change and evolve, particularly a living language such as English. At the same time he just couldn't understand how a perfectly good word, schedule, could be corrupted by his American cousins into an absurdity such as 'skedule'. I told him it was because we went to different 'shools' together. It seemed to satisfy, we had another pint and the subject was closed.

Your lively editing of $E T$ makes it a much-looked-for item in the mail. Thanks so much for your efforts! I suspect it may be a labor of love . . .

Brian S. Ward Albuquerque, New Mexico, USA

\section{Eternal vigilance}

In ET15 Professor emeritus Kurt Waechtler from Berlin denied that the state of a language indicates the state of the world. His 'hypostatization' is a magisterial term, and it is clear that a language is not an organism; but one does not need to be an academician to realise that words and the way we use them have to be an index of the society in which they are formed and used. Of course they do not mirror that society 
exactly, but (a) usages are affected by environment, outlook and behaviour, and (b) usages proceed to affect our attitudes, reactions and activity. It is a continuous process of (largely unconscious) positive feedback. Without being uncritical Cassandras and Jeremiahs, let us examine it critically and with 'eternal vigilance'.

David I. Masson, Leeds, England.

\section{A Japanese rag-bag}

The eight features that Kinoshita (ET 15, Jul 88) claims to characterize Japanese language habits seem a ragbag of ad-hoc, kore mo kore mo, suggestions put together for the occasion. Not that his fellow countrymen would not agree that he is right. However, without reading them with Japanese glasses, if I may, they appear contradictory.

The excessive use of polite language (3) with the solicitous meddlesomeness (6) would not indicate a dislike for specifying details (7). However with an awareness of status differences the contradiction is resolved. To airline passengers (paying customers) or when struggling in English (non-Japanese English speakers are sat on the high horse), addressors get long on solicitous frippery, while the toffs dispense with details for their minions to supply.

Kinoshita also repeats the old saw about Japan as a homogeneous society cut off from the outside world. Japan has not been cut off from the world for the last century, and to keep considering Japan as unique because of what happened before Napoleon, belittles the very real effort that is put into learning English in Japan.

The difficulties Japanese experience when learning English are not unique. Learning a second language is a complex affair and a frank appreciation would ease the process. Hiding behind historical and pseudo-

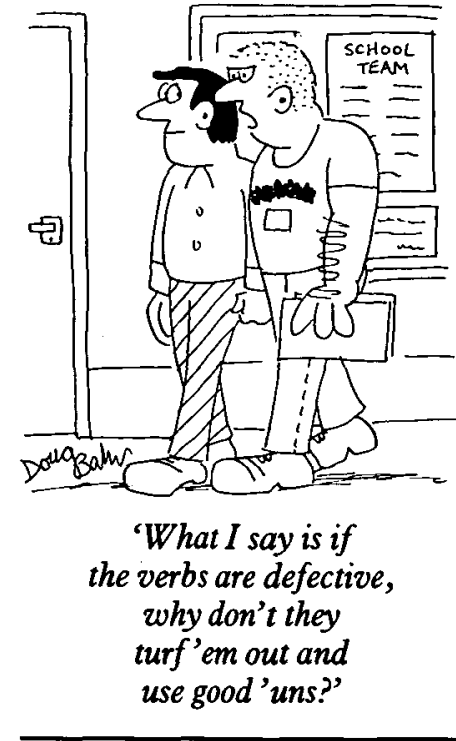

psychological rationalizations to put off the study serves noone.

Torkil Christensen, Sapporo, Japan.

\section{An RSA 'readathon'}

To get a book into the hands of as many South African children as possible is the very worthwhile aim of the recently formed Children's Book Forum. The Forum was formed as a result of a symposium held in 1987 at the University of the Western Cape - a university catering for brown or 'coloured' people primarily but does not exclude black or white students. 'Our greatest wealth lies in our children. South Africa needs now and in future South Africa will most definitely need a literate population. It will need not only people who can read but people who do read'. The foregoing was taken from a daily newspaper article and I was intrigued to learn that the Forum plans a national 'readathon'.

L. Hilton,

Somerset West, Republic of South Africa.

\section{The use of 'recently'}

As a non-native speaker of English, I have for years observed the way the adverb recently behaves in English sentences; and I now believe that the word is very rarely used in sentences with verbs in the present tense.

Apparently unaware of this, most Japanese students of English, be they beginners or advanced learners, tend to write such sentences as 'I do not read much recently because I am pressed with schoolwork', 'Recently the writer is working on a life of Milton', 'Recently we do not attend church as regularly as we used to', and so forth. I should say that this use of recently is definitely unusual.

Regrettably, however, ELT dictionaries such as $L D O C E$, $C U L D, O A L D C E$, and $C O B U I L D$ do not provide any information, couched in specific terms, about this matter, though they duly give illustrative sentences showing the use of this adverb. As far as I know, the same is true of H.W. Fowler's authoritative Modern English Usage, Michael Swan's more upto-date Practical English Usage, and many other books of English usage.

I wonder if this mistaken (to me) use of recently is peculiar to Japanese learners of English. Or do neither the editors of the ELT dictionaries nor the authors of books of English usage see the necessity of providing usage notes about the proper use of the adverb?

\section{Minoru Kaneko,} Tokyo, Japan.

\section{So it goes}

In response to Ms. ClevelandPeck's query and comments about the use of 'go' for 'say' (ET15), an identical phenomenon has existed in the US for at least 25 years. The usage seems to have arisen among workingclass teenagers, but has begun to spread across class lines (owing to heterogeneous peer groups in American public schools?). It seems to be limited to rapid accounts of conversations with third parties. 
I have never heard the past tense, and suspect that we are dealing with at least an historical present, but more likely an aoristic. Plural examples cited by $\mathrm{Ms}$ Cleveland-Peck could be ascribed to far more stringent grammatical training in the UK, than in the US.

The prevalent form seems to be 'goes', regardless of person or number. Other verbs, can take on like colouring: 'I looks at him and I goes ....' Dominance of the third singular form seems to lend credence to Calvert Watkins' contention (Indo-European Origins of The Celtic Verb, Part I, Dublin, 1962) that this tends to be the unmarked member of a conjugational system.

As to the origin of this usage, it is worth noting that the American Heritage Dictionary gives as an eleventh meaning for go 'make a specified sound: The glass went crack,' and Chambers has 'to sound (as a bell, gun).'

David H. Jerrett

Ipswich, Massachusetts, USA.

\section{Hearing and going}

Patricia Cleveland-Peck asks (ET15) for light to be cast on the 'new' use of 'to go' as an alternative to 'to say' as an introduction to speech.

Surely this is not new: I heard it from all ages of mouth whilst growing up in the 'fifties in Lancashire and I hear it now in street, school and broadcasts. 'Hear' is the key, and its use explains why it occurs rarely in written form: when someone says, for example, 'I goes, “you'll be lucky!"' the recalled utterance is normally rendered in the (supposed) tones of the original encounter. It is sometimes accompanied by non-verbal gestures to re-inforce the effect. In other words, it is acted. Its use normally has the (perhaps unconscious) intention of showing the speaker in a dominant or triumphant role. Seen in this way, 'said' would not be an ade- quate introductory verb for such a 'performance'. The manner of delivery can be established in written form most easily by the use of stage-direction verbs such as 'shouted', 'whispered' and so on.

Peter Kay,

Newport, Shropshire, England.

\section{Miscellany}

(1) In your July issue, Agnese Grammatica of Turin, Italy, asks about the use of the genitive instead of of with thing nouns. The Comprehensive Grammar of the English Language, which you cited, strangely omits reference to a consideration which I think would help this reader: All of the quotations offered are formal or literary, not colloquial. In normal conversation or nonliterary writing, native speakers would not say 'the room's crevices', 'the fire's bright hooks', 'the ladder's top end', or 'the building's warmth'. We would say 'the crevices of the room', 'the bright hooks[?] of the fire', 'the top end of the ladder', and 'the warmth of the building'.

(2) In the same issue, Patricia Cleveland-Peck of Sussex, England, asks about the new use of go for say, as in That ... boy . . . goes, Do you know Tina? She thinks it doesn't sound American, but I can assure her that it is very widespread here among young people and may well be of American origin. I believe it almost certainly derives from a common use of go with animal sounds, as in Cows go 'moo'. I cannot find this meaning in Webster's Third NID or in the $O E D$, but it may derive from the use of go for the sounds of inanimate objects, as in the gun went and the bell went, which both dictionaries report.

(3) In the same issue, Harry Morgan of Surrey, England, comments on the spoken use of " "quote . . . unquote" (with ... even little gestures in mid-air)'. He locates this usage 'in our time' and says that he thinks it is 'mostly postwar'. My mother told of her school principal in Brooklyn, New York, circa 1908, who would put down a load of books on the floor in order to wiggle two fingers of each hand to signify quotation marks (Americans, of course, require two fingers, as we write ". . ."). Note also that Americans now commonly say both words 'quote unquote' before or after the quoted words, thus leaving the boundaries of the quotation unmarked.

(4) Graham Pointon's article, The BBC and English Pronunciation, reviews many interesting changes in the BBC's recommendations over six decades. Except for garage and kilometre, all the changes mentioned are in the direction of American usage.

Dr. Sheldon Wise, Director, English for Specific Purposes, American Language Academy, Rockville, Maryland, USA.

\section{Aspirates and articles}

I was puzzled by the reference by Agnese Grammatica, on p.56 ( $E T$ 15) about the aspirates. I did not think that there was any problem on this subject. We were taught that you must write the words in the way that they are spoken. This means that if the letter ' $h$ ' is silent then you must use the word 'an', and otherwise you always use ' $a$ '. This would mean 'a hotel' but 'an honour' and so on with other words. This must be so, as otherwise you would have to sound the words in a way different from that in which they were written.

I like the idea of publishing one or two pages of text in perfect English, and I have a friend who might be of assistance here. $\mathrm{He}$ is knowledgeable almost to the point of being pedantic about correct English, and only the other day, wrote to point out to me a publication, which used the phrase, 'the hoi polloi', which he complained was obviously wrong 
because 'hoi' came from the Greek work for 'the'. This was news to me. He might be able to edit a page and possibly even to generate a page of perfect text by himself. We are both members of the 'Queen's English Society' which meets regularly at Arundel.

Arthur Denton, Littlehampton, West Sussex, England.

\section{An}

Only a small word but charged with significance. During the six centuries (406-1066) that English (fundamentally Germanic Anglish-Saxon) was the language of England, an was used both as indefinite article and as numerical adjective:

(1) There is an apple on the table

could mean either

(2) There is an apple on the table

or

(3) There is one apple on the table.

This situation obtained till 1066 when the Norman Conquest relegated English to its lowly status as dialect of a conquered people. As so beautifully portrayed in Scott's Ivanhoe, the natives kept talking English though French was now the official language spoken in Parliament, in the courts, and in international communication. More important, most literature was written in French. Even Chaucer $(1340-1400)$ wrote his first verse in French and translated a good deal of French poetry. It was not till 1362 that a law was passed making English the official language again. Ironically, the law was written in French.

During the three centuries the French occupation lasted, so many French words were absorbed by the native language that vocabularywise it is French rather than Germanic. One estimate is that our 4000 basic
Anglish-Saxon words are outnumbered by over 40,000 French. Open the Larousse Dictionaire Illustré almost at random and you find near 40 of the approximately $\mathbf{5 0}$ definitions on most of the 1111 pages recognizable as the ancestors of their English equivalents: personne, perspective, perversité, etc.

Not among them is an for the adequate reason that French, like the other Latin derived languages has no word for the indefinite article: Italia est terra. Instead they use a clipped form of the numerical adjective unus (one for both functions). Accordingly, un pied (Fr.), un pies (Sp.), un piede (It.) may mean either 'one foot' or 'a foot'. Antithetically, modern German, lacking the influence that gave us our numerical adjective, is still in the position we were in prior to 1066 : ein Fusz [sic] may mean either 'a foot' or 'one foot'.

The query about an in ET15 illustrates how our antigrammarians have enfeebled the advantage history has given us over our sister languages. Webster's Third proclaims that the function of a dictionary is not to give an editor's opinion of what a word ought to mean, but only to record the meaning, spelling, and pronunciation of a word as it is actually used. A word becomes standard when large numbers of

\section{Minutes of a minute-long year- end board meeting}

Votes were unanimous, all pre-quizzed.

Highballs inanimate, all prefizzed.

Collars were comfortable, all pre-shrunk

Views were compatible, all pre-thunk.

Alma Denny, New York people grammatically or not, use it.

Thus, an editor turns himself from being a lexicographer interested in the etymology of a word into a poll taker of the numbers of persons who use it a certain way. So, in defining an it gives eight ways in which it is used. First, it is used invariably before words beginning with a vowel letter and sound. The other seven are examples of some people's using an before consonants. Fowler's valid article on $a n$ in Modern English points out why most of these examples are misuses that have about disappeared (1965).

Even the Oxford Dictionary of English Etymology, usually so reliably informative, is by no means lucid. The entry under an calls it a variety of $a$ as if it were another word: 'It is used before vowel sounds and before unstressed syllables having initial $h$, "an historical"'. In the entry under $a$ however, ' $a$ is called a reduced form of an and is used before a word beginning with a consonant.' Because no examples are given or reference made to exceptions (an hour, a eulogy), one wonders if the same person made both entries. At any rate, the addition of 'sound' to 'consonant' would have eliminated the fancied need for 'explanations' of exceptions.

There must be a basic reason for the clipping of the $n$. As pointed out in Our Language, we have a tendency to skip pronouncing the word endings when they get in the way of starting the following word. It is easy to say 'an orange' or 'an hour'. But if the following word begins with a consonant sound we feel an impediment: 'an hand', 'an tire', 'an eulogy'. The writer on usage who tells us that it is correct to say 'an historical' seems indifferent to the fact that what determines clipping is not the spelling of the following word, but its pronunciation. How universal the tendency is can be attested by anyone who visits the country 
whose language he has studied. He has a hard time understanding the natives because they do not say the 'I am going to telephone him' he has learned, but their version of ' $I$ ' $m$ gonna phone ' $m$ '. All the above can be summed up in the simple yet comprehensive definition: 'An Indefinite article. $\mathrm{OE}$ 'an' = one, an. Used before words beginning with a vowel sound. Drops its $n$ before consonant sounds.'

\section{John Peters \\ Springfield, Ohio, USA.}

\section{An r-less accent?}

I have a question in loose connection with Graham Pointon's article 'The $B B C$ and English Pronunciation' (ET15). It is: What is going on with the liquids $/ 1 /$ and $/ \mathrm{r} /$ in English English? This question has occurred to me for the following reasons:

(1) For a couple of centuries new RP has been characterised by weakening of any $/ \mathrm{r} /$ which does not precede a vowel. Indeed, as is well-known, it is now mainly only in the south west of England that nonprevocalic $/ r /$ is much to be heard in the speech of any English people.

(2) In Kent, where I live, colloquial non-RP speech features a pronunciation of non-prevocalic /1/ which sounds a great deal like $/ w /$, though, evidently, with less rounding of the lips. In fact, it seems common throughout the south east of England for hill and milk, for example, to be pronounced as $/ \mathrm{hIw} /$ and $/ \mathrm{mIwk}$, respectively. This leaves a great many English people with prevocalic liquids only.

(3) There is a pronunciation of prevocalic /r/ which I took to be a speech defect when I first heard it on coming to Britain. The pronunciation $I$ have in mind tends to be associated by Americans and Canadians with Bugs Bunny's would-be nemesis, Elmer Fudd, who turns all prevocalic $/ \mathrm{r} / \mathrm{s}$ into something very like $/ \mathrm{w} /$

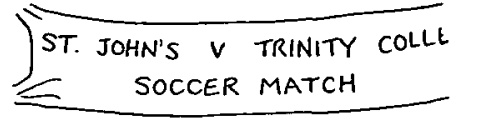

held to be derived from the French parler, which in English gives parley. In view of the Anglo-French origins of this language it might be quite appropriate to christen it Parley: 'Do you speak Parley?' doesn't sound bad.

Professor Christophersen also implies that English means 'of England'. It certainly didn't mean that originally, since English was called English long before England was called England. The original meaning of English was probably 'of Angeln' (in Schleswig). It was, in fact, Professor Christophersen's Danish ancestors who named England after the language. The English themselves called it Bretenland and their kings were called Bretwaldas ie rulers of the Brits.

The English may have originated the language, but the British and the Scandinavians changed it.

It seems to me that there is a perfectly good term for optimum/native language. It is idiom.

An Irish person could well say that Irish was his language, but that English was his idiom. He might add that he had a good command of Irish although his pronunciation was not quite that of an idiomatic speaker. To say that his accent was not that of a native speaker would be to deny his nationality.

The object of most bilinguals is probably to become fully idiomatic in two languages. This ideal may not often be attained so that most bilinguals, rather than having two idioms, will have an idiom and another language in which they are not fully idiomatic. They might be quite at home

\section{The Beurla idiom}

Paul Christophersen toys with the idea that we might adopt the Scottish Irish word Beurla in place of English as the name of the language. The Irish Irish form of this word is Bearla and the Manx Irish is Baarla. It is
Readers' letters are welcomed. ET policy is to publish as representative and informative a selection as possible in each issue. Such correspondence, however, may be subject to editorial . adaptation in order to make the most effective use of both the letters and the space available. 
in the language in most respects, but if their accent gave them away they could not be said to be idiomatic speakers.

If idiom is to be used in a more precise and scientific way looser uses of the word will have to be avoided e.g. when it is used as shorthand to mean an idiomatic expression.

I would be interested to read Professor Christophersen's com- ments on the points raised in both letters.

Robert Craig, Weston-Super-Mare, Avon, England.

\title{
ROUNDUP
}

\section{Words from the front}

\author{
FOHN SIMPSON, co-editor of the 'Oxford English \\ Dictionary', investigates some questions raised by \\ readers in recent issues of $E T$.
}

SEVERAL months ago I was contacted by the agency which handled advertising for Audi cars: was I going to add "Vorsprung durch Technik" to the $O E D$ ? I replied that although there was strictly speaking no lexicographical reason for excluding the phrase from the Dictionary, we had little evidence that it had passed into general currency as anything but an advertising slogan, and that it would therefore be omitted. Fifty years ago we might have said much the same to Bovril, who popularized "that sinking feeling" with spectacular success in poster adverts for their product: in this case the phrase has achieved widespread use, and is now in several dictionaries. Advertisements and product packaging are a prolific source of catch-phrases, which are themselves often set in quotation marks. Many, like "Every picture tells a story" (for Doan's Backache Kidney Pills) remain household words long after the products they advertised have been overtaken by new brands.

It is quite true ("Of quotation marks and potato crisps", Graham Brown; October) that this represents an unusual use of quotation marks. Typically, an advertiser uses quotation marks to imply that the quoted phrase is somehow a testimonial: "the best to you each morning" - and so the punctuation has its origin in what purports to be direct speech. At other times, the manufacturer's name itself is cited in advertisements or on packaging in this way: "Brymay" matches, or "Princes" salmon. This seems to imply a conversational familiarity with the product, to which the advertiser wishes to alert the buyer (perhaps subliminally). Again it is just a short step from true direct speech. In fact, this marketing technique was commoner twenty or thirty years ago: nowadays quotation marks are less frequent in such contexts. Presumably they are thought of as distracting clutter.

The potato crisp packet referred to in $E T$ highlighted "flavour wise", "crinkle-cut", "more" than a "snack", and "tomato" sauce, amongst others. The first three could be grouped together as quoted testimonials: though this does run counter to much modern advertising practice, and will quite rightly raise the hackles of purists almost as much as the indefensible but widespread greengrocer's apostrophe ("Fresh Tomato's"), or the supermarket's casual "best before see top of packet": both of which would defeat automatic translation. For the record, I am told by the manufacturers that the quotation marks were introduced for two solid marketing reasons: (1) to catch the attention of potential buyers; and (2) e.g. in the case of "tomato" sauce, to highlight the selection of new flavours. I am also told that the quotation marks have now been removed from around the names of the new flavours (though they have been retained elsewhere). Advertisers are always looking for ways to arrest the attention of the public: in this case, they may have succeeded.

It could be argued fairly convincingly that each generation has its own dialect of English, and that all of the other generations object to it. I was delighted to read that Patricia Cleveland-Peck did not take sides in 